\title{
Life History and Personality Characteristics of Marital Aggressors: Psychoanalytic Contributions
}

\author{
Gabriela Quadros de Lima Stenzel ${ }^{1}$ (1) https://orcid.org/0000-0002-9483-3868 \\ Carolina Saraiva de Macedo Lisboa ${ }^{1}$ (1) https://orcid.org/0000-0002-2199-9824
}

\begin{abstract}
Research indicates that trauma (sexual, physical, and emotional abuse) is a factor commonly present in the life of marital abusers. This study aimed to investigate the life history characteristics and personality of men who perpetrated violence against women and were detained in the Central Prison of Porto Alegre, Brazil. We also identified sociodemographic characteristics, the presence of psychopathological symptoms and understood the intrapsychic dynamics involved in the participants' marital choice, as well as their perception regarding the experience of detention. Three participants filled out a personal data sheet, answered the Rorschach method, the MINI Interview, and participated in three semi-structured interviews. The interviews were examined from the interpretative analysis technique based on psychoanalytic theory. The results allow us to understand the violence committed by the participants as a result from a life story marked by traumatic experiences that produced narcissistic flaws and the expression of aggressiveness.
\end{abstract}

Keywords: violence in the family, psychic trauma, narcissism

\section{História de Vida e Características de Personalidade de Agressores Conjugais: Contribuições Psicanalíticas}

\begin{abstract}
Resumo: Pesquisas indicam que o trauma (abuso emocional, físico e sexual) é um fator comumente presente ao longo da vida de agressores conjugais. Este estudo objetivou investigar as características da história de vida e de personalidade de homens que perpetraram violência contra a mulher e estavam detidos no Presídio Central de Porto Alegre. Identificou-se também características sociodemográficas, a presença de sintomas psicopatológicos e se compreendeu a dinâmica intrapsíquica envolvida na escolha conjugal dos participantes, bem como a percepção deles a respeito da vivência de detenção. Três participantes preencheram uma ficha de dados pessoais, responderam ao Método de Rorschach, a Entrevista MINI e participaram de três entrevistas semiestruturadas. As entrevistas foram examinadas a partir da técnica de análise interpretativa baseada na teoria psicanalítica. Os resultados permitem compreender a violência cometida pelos participantes como decorrente de uma história de vida marcada por vivências traumáticas que produziram falhas narcísicas e a expressão da agressividade.
\end{abstract}

Palavras-chave: violência na família, trauma psíquico, narcisismo

\section{Historia de Vida y Características de Personalidad de Agresores Conjugales: Contribuciones Psicoanalíticas}

\begin{abstract}
Resumen: Los estudios apuntan que el trauma -ocasionado por abuso emocional, físico y sexual- es un factor comúnmente presente a lo largo de la vida de los agresores conyugales. El presente estudio objetivó investigar las características de la historia de vida y de personalidad de hombres quienes habían cometido violencia contra la mujer y que estaban detenidos en el Presidio Central de Porto Alegre. También se identificaron las características sociodemográficas, la presencia de síntomas psicopatológicos, y se comprendió la dinámica intrapsíquica involucrada en la elección conyugal de los participantes, así como su percepción acerca de la vivencia en la prisión. Tres participantes llenaron una hoja con datos personales, respondieron al método de Rorschach, la entrevista MINI y participaron en tres entrevistas semiestructuradas. Se analizaron las entrevistas por medio del análisis interpretativo con base en la teoría psicoanalítica. Los resultados permiten apuntar que la violencia cometida por los participantes es consecuencia de una historia de vida marcada por vivencias traumáticas que les produjeron fallas narcisistas y la manifestación de agresividad.
\end{abstract}

Palabras clave: violencia en la familia, trauma psíquico, narcisismo

${ }^{1}$ Pontificia Universidade Católica do Rio Grande do Sul, Porto Alegre-RS, Brazil

Support: Paper derived from the PhD thesis of the first author under the supervision of the second, defended in 2015, in the Graduate Program in Psychology, Pontifícia Universidade Católica do Rio Grande do Sul, Brazil. This study was financed by the Coordenação de Aperfeiçoamento de Pessoal de Nível Superior - Brazil (CAPES) - Finance Code 001, through the program CAPES/PROSUP.

Correspondence address: Gabriela Quadros de Lima Stenzel. Rua Cabriuva, 250. Cantegril 2. Viamão-RS, Brazil. CEP 94.451-182. E-mail: gabrielaqlima@gmail.com.
It is understood that domestic violence against women is expressed in a context of interconnection of conscious and unconscious aspects of the couple, and not only based on the victim's vulnerability. In this sense, scholars mention trauma as a factor present in the life story of marital aggressors (Fulu, Jewkes, Roselli, \& Garcia-Moreno, 2013; Hirigoyen, 2006; Nardi \& Benetti, 2012; Razera \& Falcke, 2014; Tondowski et al., 2014; Varón \& Otero, 2014). Mistreatment during childhood, emotional, physical 
and sexual abuse, and witnessing violence between parents are examples of traumatic events present in the lives of many of these men (Fulu et al., 2013; Stenzel \& Lisboa, 2017). Therefore, it is believed that marital aggressors may have a history marked by situations of difficult psychic development, which favor the emergence of violence in their ways to relate with other people.

In terms of the characteristics of human development, Asnis (2013) points out that Freud understands the drive component of cruelty as being natural from an early age, since the ability to sympathize with the pain of the other is incremented at a relatively late time. The absence of the compassion barrier represents the risk that this type of bond established in childhood, between cruel and erogenous drives, which enable the feeling of pleasure and satisfaction, to remain as a way to establish relationships even into adulthood. Therefore, for psychoanalysis, as the author points out, education and an environment marked by love shall influence directly in the development of the compassion barriers, which will serve to mitigate the prevalence of cruelty and destructiveness drives.

Also, psychoanalysis presents itself as a discipline that offers important theoretical resources to understand the problem at hand, conceptualizing the traumatic experience (coming from child abuse in this study) as an "excess" that cannot be represented physically. Thus, when anguish and pain reach an intolerable level, the feeling of breaking of the ego arises in the person, approaching the experience of death and annihilation (Laplanche \& Pontalis, 2001). It is worth noting that the intensity of the pain, which shall define an experience as traumatic, is influenced by the uniqueness of each life story. Therefore, it seems relevant to resume Freud's arguments (1920/1996), when he claims that the loss of love in the early days of existence entails a constant loss of the sense of self. The narcissistic scar produced by this loss is an important contribution to the establishment of the feeling of inferiority. We can notice that it is the narcissism (the image of the self), described by Freud as a basic and structuring process of subjectivity, that sickens and suffers. The ideal self does not give space to the self's idea, place of alterity. Narcissism presents itself in the form of subjectivation cracks that are difficult to repair. Thus, the experiences seized by the psychic apparatus as excesses are difficult to represent and symbolize. In addition, how the environment reacts to these events shall leave inevitable marks in the notion of existence of the individual (Freud, 1920/1996). In this sense, and analyzing the phenomenon of domestic violence against women perpetrated by intimate partner, it is possible to realizes that it is often an attempt to heal a hidden wound and to repair a past of suffering in the current romantic relationship.

Considering the above, this study aimed to investigate the life story and personality characteristics of marital aggressors under arrest at the Central Prison of Porto Alegre (PCPA), due to the Law Maria da Penha (Law No. 11.340, 2006). This law classifies the types of domestic violence, prohibits the application of fines to offenders, provides for flagrant arrest, and extends the decided sentence for up to three years. Therefore, it represents a milestone in the fight against domestic violence. We also intended to identify the participants' sociodemographic characteristics, the presence or not of psychopathological symptoms, as well as understand the intrapsychic dynamics involved in the participants' marital choice, in addition to their perception regarding the experience of detention.

\section{Method}

\section{Participants}

The three participants of this study were selected according to the inclusion criteria (being aged 18 years or more and being under arrest on the basis of Law Maria da Penha), as well as the exclusion criteria (present psychotic disorders and/or make use of medication that alters the logic and reasoning ability). The number of participants was defined by the criterion of data saturation. Below, we describe the characteristics of the participants' arrest (fictitious names).

Case João - João is 63 years old and when he started his participation in the research he had been under arrest for 10 days. João had been married for 43 years when he killed his wife with shots from a firearm. The participant recounts that his wife and daughter had physically harmed him due to intrigues of the community that made his partner jealous.

Case Carlos - Carlos is 47 years old and had been under arrest for one year and two months when he started to participate in the study. Carlos reports he accidentally shot a firearm at his partner, culminating in her death.

Case Vicente - Vicente is 45 years old and had been under arrest for three months at the time he began to participate in this study. Vicente physically assaulted his former partner, after a previous assault and even though she possessed a restraining order against him. The participant mentioned to have assaulted his former partner as a way to "blurt out" (sic.) since she abandoned their son at the age of four.

\section{Instruments}

A Personal and Sociodemographic Data Sheet was used to characterize the sample. The Rorschach Method - Comprehensive System (Exner, 1999) was used to obtain information regarding the participants' personality characteristics. This instrument stands out for the quality of its psychometric studies and for the wide recognition of psychologists all around the world concerning tests that assess personality (Nascimento, 2010). The Mini International Neuropsychiatric Interview - MINI Interview (Amorim, 2000) was employed as an exclusion criterion and to determine the presence or absence of psychopathological symptoms. Also, the three men took part in a series of three interviews, guided by, respectively, three major axes: a) life story, b) marital choices and 
situations of violence in romantic relationships, and c) current arrest situation.

\section{Procedure}

Data collection We contacted the direction of PCPA and the Judge of Criminal Executions of Porto Alegre to clarify the objectives of the study and request authorization to carry it out within the Central Prison. The application of the instruments happened in four meetings of approximately one hour. In the first meeting, the Personal and Sociodemographic Data Sheet, the Rorschach method, and the MINI Interview were applied. The other three meetings were reserved to carry out the semistructured interviews. The interviews were recorded on audio.

Data analysis The Rorschach protocols were classified and the processing of structural summaries was conducted through the software RIAP version 5.00.137. The scores found were analyzed from the national normative reference (Nascimento, 2010). Then, the qualitative interpretation of the results was carried out based on the test's manual (Exner \& Sendín, 1999). For this study, we used the most relevant data regarding the current functioning of the participants. The content of the interviews was analyzed according to the method proposed by Erickson (1997), named Interpretative Analysis. This method allows the researcher to carry out an analysis that leads to a logical generalization of the findings, from the specific manifestations of the experiences of each participant. The interpretation was performed from the theoretical resources offered by Psychoanalysis and allowed understanding the information shown by the Rorschach method.

\section{Ethical Considerations}

The research project was approved by the Research Ethics Committee of the Pontifícia Universidade Católica do Rio Grande do Sul, under opinion number 746,770. The three men signed the consent form, expressing their agreement to participate in this study, despite the prior authorization granted by the Judge of Criminal Executions. In addition to the formal and ethical aspects, it should be noted that our intention was to provide a space of careful listening, based on psychoanalytic assumptions and ethics, approaching a clinical intervention as much as possible.

\section{Results}

Table 1 presents the personal, sociodemographic, and arrest-related characteristics of the participants. It should be noted that for two aggressors, the behavior that led them to be arrested was the murder of his companions.

Table 1

Personal, sociodemographic, and arrest-related characteristics of the participants (Personal and Sociodemographic Data Sheet)

\begin{tabular}{|c|c|c|c|}
\hline $\begin{array}{l}\text { Personal, sociodemographic and arrest-related } \\
\text { characteristics }\end{array}$ & João & Carlos & Vicente \\
\hline Age & 63 & 47 & 45 \\
\hline Education level & Elementary school & $\begin{array}{l}\text { High school, Mechanics } \\
\text { technician }\end{array}$ & $\begin{array}{l}\text { Some higher } \\
\text { education (Law) }\end{array}$ \\
\hline Last occupation & Retired Mechanic & Telephony technician & Construction worker \\
\hline Religion & Catholic & Evangelical & Catholic \\
\hline With who did you live & $\begin{array}{l}\text { Wife, daughter, and } \\
\text { granddaughter }\end{array}$ & Partner & Son \\
\hline Time of relationship & 43 years & 2 years & 6 years \\
\hline Partner's age & 59 & 37 & 29 \\
\hline Partner's education level & Elementary school & Elementary school & High school \\
\hline Partner's occupation & Housewife & Sales person & $\begin{array}{l}\text { Kitchen assistant in a } \\
\text { restaurant }\end{array}$ \\
\hline Number of children with the partner & 2 & --- & 1 \\
\hline Assault that caused the arrest & Murder & Murder & Physical \\
\hline Detention time & 10 days & 1 year and 2 months & 3 months \\
\hline Previous arrests & No & No & No \\
\hline
\end{tabular}

Results from the MINI Interview indicate that João is the only participant that diagnosed as psychopathological (Major Depressive Episode with Current Melancholic Characteristics, Past Hypomanic Episode, Current Panic Disorder with Agoraphobia, Social Phobia, Current Alcohol Abuse, Current Generalized Anxiety Disorder). This participant does not use any type of medication and is not undergoing psychiatric/ psychological treatment, having been under arrest for only 10 days. The other two participants did not use any psychotropic medication, which can justify the absence of symptoms.

Concerning personality characteristics, the information that draws the most attention in the three cases studied is 
the fact that the interpretation of the Rorschach method (Exner \& Sendín, 1999) point to damage in the capacity of stress control and management as the most relevant information regarding the current psychological functioning of the participants. This grouping reveals information about the psychological resources available for the individual to face the excessive discomfort felt. João's answers to the Rorschach Method show that he is facing a state of stimuli overload resulting from his difficulty to use the appropriate psychological resources to handle life's internal and external tensions. The participant presents risk of manifesting anxiety, tension, nervousness, and irritability. People with this type of difficulty tend to have low tolerance for frustration, as well as being prone to emotional outbursts. This participant demonstrates a level of emotional stress that damages the comfortable modulation of affection. The data obtained show the conflicts present throughout his life story that possibly stopped João from getting the psychological resources needed for an adequate adaptation to interpersonal relations.

The information concerning situational stress are the ones that stand out in the interpretation of Carlos's protocol data. This set of variables refers to moments in which the control ability changes temporarily, due to the presence of painful feelings. This increase in tension originates in particularly difficult occasions that are happening in the life of the individual. Situational stress overlaps a preexisting chronic stressing stimulus load, thus hindering the self-control ability and creating a strong tendency toward impulsivity regarding what he thinks, says, and/or makes.

In the case of Vicente, the test suggests that as long as this participant lives in an environment where stress factors are controlled he shall be satisfied with his life. On the other hand, Vicente can present weak control of impulses, distress, and low tolerance to frustration when not safe from stressgenerating situations. Also, he seems to be less able than most people to deal effectively with everyday experience, especially regarding social situations.

Finally, the assessment of the interviews, from the Interpretative Analysis technique (Erickson, 1997), allowed the identification of three assertions that shall serve as a support to integrate and discuss the results. They are: "Helplessness and violence as marks in the life story and psychic constitution of marital aggressors", "Marital choice and the exercise of violence as manifestations of the narcissistic failure", and "Law Maria da Penha and the reproduction of the sense of abandonment".

\section{Discussion}

The results from this study indicate that the three participants have major difficulties related to the lack of psychological resources to deal with situations that generate a high load of emotional stress and/or that challenge them (Rorschach Method). Therefore, we sought to understand, through the characteristics of their life stories, how this "lack" was introduced in their psyches. Henceforth, we discuss the assertions produced after carrying out the Interpretative Analysis based on the psychoanalytic theory.

\section{First assertion: Helplessness and violence as marks in the} life story and psychic constitution of marital aggressors

The stories of João, Carlos, and Vicente demonstrate the presence of helplessness and violence from an early age. João narrates the experience of extreme violence he suffered by his father, as well as the passivity hiss mother as a witness in the face of such violence:

I was hit with a belt because I peed in the bed. Also because of pacifiers. I do not know if that is what affected me. He [father] has always been rough, he was violent with his family. He murdered a person too, this impacted me a lot. I got beat up with a machete. The mother was always silent, poor thing. She never did anything. He took the machete and hit me on the back, if it was with the edge, it would have cut me in the middle. He hit me once, twice, and I fell. This is something I will never forget. I opened up the can of olive oil to make a truck to play with. It was a mistake!

The psychic trauma can be conceptualized as an event in the individual's life characterized by its intensity, by the inability of the person to react properly, by the disturbance it generates, and by the lasting pathogenic effects it causes in the psychic organization. In economic terms, what is traumatic represents an excess in relation to the individual's capacity to psychically develop the excitement he receives, discharging them. The state of helplessness, in its turn, is considered the prototype of the traumatic situation causing the anguish. In this sense, since birth, human beings require care from another person to have their needs met. Thus, the first relationships with caregivers leave marks on the psyche throughout development, appeasing or not what is considered as excessive and, therefore, traumatic, by the psychic apparatus (Laplanche \& Pontalis, 2001). In João's life story, many situations experienced by him seem to have had a traumatic effect, because he witnessed various forms of violence by his father, against himself, his mother, brothers, and others, in addition to the mother's silent witnessing. It is important to highlight that trauma is not in itself a pathological event, but it can be subjectivant or desubjectivant to the individual depending on the relationship it establishes with the environment (Canavêz, 2013). It called our attention that João questions himself about the possibility of having been affected by his father's violence to the point of also being violent with his partner. Such questioning points to an important ability for reflection that can assist João to develop the pain and suffering arising from his life story. It should be noted, however, that the presence of professionals capable of offering support is crucial during testimonies of experiences of previous helplessness and violence in life as well as those of current extremely vulnerability. Carlos and Vicente also narrated situations experienced as being of helplessness and violence: "I started working when I was only 11 years old" (Carlos).

When she hit me [mother], she hit me hard. I had to throw myself under the bed and she hit me in the face, 
she had nowhere else to hit. She used the belt, punished me by making me kneel on beans. She was pretty strict (Vicente).

I do not know if that affected me so far... But it kept going, and he [father] taught me to shoot with a gun because my brothers had no interest in it, and at that time we could hunt in the woods, you know... Then, he gave me a gun, I was 12 years old (João).

The presence of aggressive delimits a way to establish relationships with the aim of harming the other from a violent motor action or negative behavior, such as, for example, refusing to help (Laplanche \& Pontalis, 2001). Carlos reports situations in which he felt the need to take care of himself alone and from a very young age. João recalls that he was encouraged by his father to use a firearm, even as a way to establish an affective bond between them through an activity related to violence. Vicente experienced repeated violent situations and although he considers he had good parents, he demonstrates that the fact he was abandoned by his biological parents marked his future behavior:

I am adopted, my mother is actually is my grandmother, my father had no conditions to raise me. Thus ,I would never accept to let someone adopt my son, would never leave him without a father. Because my father left me without a father, even if he was actually my brother. But even so, I said: I will never do that with my son, I am going to raise my son.

In situations of separation or loss, the internal tension increases progressively to the point in which the individual become unable to master the excitements, which defines the generator state of feeling helplessness and the need to be loved (Laplanche \& Pontalis, 2001). It is known that the ego proceeds the early affective ties with the world, such as how much the child was desired. Thus, the loss of love in the first moments of life stands out as a hindrance feeling good about himself. The current abandonment in his life story permeates it by the traumatic dimension, considering the fact that the child is unable to perform symbolic developments to deal with so much distress (Freud, 1920/1996). It is also noteworthy that the lack of love during childhood will significantly influence the individual's inability to develop the compassion barriers capable of mitigating the predominance of cruelty drives throughout life (Asnis, 2013; Asnis, Werlang, Macedo, \& Dockhorn, 2012). In Vicente's story, as well as the mark of the birth mother's abandonment, violence is noticeable from the relationship that the foster mother was able to establish with him. The narcissistic scar shows itself to be present and operant, for example, in the marital choice that caused Vicente to once again face the possibility of abandonment. His abandonment by his partner and abandonment of his child by the mother, which made him relive his own life story.

\section{Second assertion: Marital choice and the exercise of violence as manifestations of the narcissistic failure}

The study of the unconscious demonstrates that human beings do not have decision power they believe to possess concerning their choices. However, this understanding does not mean individuals stop being responsibility for their own actions. It is believed that the same is true regarding the marital choice, as it is marked by conscious and unconscious characteristics influenced by the relationships established in the families of origin (Lima \& Werlang, 2011; Lima, Werlang, \& Potrich, 2012). In the case of the study participants, as explained in the presentation of the first assertion, the relationships with caregivers were marked by helplessness and violence, establishing the mark of lack as an excess in the psychic apparatus and as a failure in the important and structuring phase of narcissism. The concept of narcissism was established as a location of libido, present in the regular course of human sexual development. Narcissism can be considered the libidinal complement of the selfishness of the self-preservation instinct, which, to some extent, can be assigned to every living creature (Freud, 1914/1996), but in a special way to the participants of this study.

Carlos's testimony denotes how much his love choice originated from the feeling of emptiness and ended up turning into violence against the partner who was unable to provide all the investment he needed. From the perception that the partner would not cure the lack of love established in the past, Carlos did not contain the expression of the death drive through his aggressive behavior, which resulted in the death of his partner:

It could happen to anyone else I could have known, to fill what was empty inside of me, and that is what happened. This will mark me for the rest of my life, this kindness that put me in here. Unfortunately, I was too good for this person and ended up in a place like this. What I understand is that all I have done for her... And she did not recognize it, and I think that this paid for most of all I have done for her.

It is important to recall Freud's claim (1914/1996), that a strong selfishness protects against sickening, but, however, we must develop a capacity to love in order to not sicken. On the other hand, we fall sick if, due to frustration, inability to love prevail. The way Carlos has been facing the fact of killing his partner demonstrates that his psychic apparatus is immersed in the selfishness of his narcissistic wound.

Freud (1914/1996) characterized two types of object choice: the anaclitic type and the narcissistic type. The first is characterized by the feeling of being in love that results from the realization of the childish conditions for love, with the objects being chosen according to the parental figures who provided the necessary security in the early stages of life. In the narcissist choice, the focus of love will be what it is, what was and what is no more, what one would like to be or the object that possesses the excellence that the ego never had. The satisfaction obtained from this kind of object choice 
consist primarily of being loved. Therefore, the dependence that ultimately establishes itself as the loved object has the effect of reducing the humble feeling of being in love, this being, therefore, the counterpoint of the narcissistic choice. The author explains that the individual who loves deprives himself of part of his narcissism, which is replaced by someone else's love for him. On the other hand, the inability to love, as a result of some sort of physical or mental disturbance, has an extremely diminutive effect on the self-esteem, which can result in significant feelings of inferiority. Thus, Freud points out that, for the neurotic, choosing a narcissistic type of object is characterized as a search, equally narcissistic, of the cure by love. In addition to Carlos, João and Vicente also showed that the choice for a narcissistic object triggered the exercise of violence against their partners, as explained below:

I ran to where the gun was and threatened: "Drop the knife or I will shoot you". She said: "You are not man enough to shoot", and then I thought: "Well, now I am", and that was the limit, because it humiliated me, demeaned me, threatened me...Good grief, they [family] did so much, right, to harm me, beat me, humiliate me... Then I was in doubt: I wonder if I did it right, or maybe I did it wrong? (João).

I ended up arguing with her, I blurted it all out, about so many things she did I was not ok with. She could have done thing differently, whatever it was, a child's love is important. I am man and I did not abandon my son, but I did not accept it, I did not like her attitude. (Vicente).

While narcissism, as a structuring factor, is at the basis of our own identity, inspiring ideals and ambitions, the pathological narcissism is the major provider of violence. These men have a need to be permanently appeased by someone, becoming dependent (Hirigoyen, 2006). João exemplifies the desire to isolate his partner in the following statement:

We got married, soon she got pregnant... She worked in a factory, then when she got pregnant I told her to quit. I got a good job, that I had perfected. Then I started to earn a little bit more, I rented a small house and told her she no longer needed to work, she should take care of the child and of the house.

It should be noted that any individual may react with anger on a given situation, but the self-esteem of a narcissist individual feeds of the the other's look, because without the other, he is nothing. It can be noticed that a narcissist seeks merger and has the need to control the other, of making the other a mirror that reflects only a good image of himself. In circumstances in which this merger is not successful, the partner is considered an enemy and the man fears being invaded by the anguish of annihilation, thus, violence (free and unrestrained expression of the death drive) becomes his way to protect himself (Hirigoyen, 2006).
She threw me away, from the house it took my entire life to build... And then comes the other man and takes everything that is mine and she gets excited and sells it all, he takes the money and kicks her to the curb and she has nothing, I have nothing, the joke is on me. I stuck around to see how far it would go, but I did not know it would end this way. But I was jealous of the house, of what was mine, hers even, after so much time together, I do not know if it was jealousy, something more... (João).

It is relevant to stress that violence occurs in the context of a relationship in which are present the characteristics of the life story of the author of this violence, but there are also characteristics arising from the relationships established by the victims throughout their lives. Carlos' testimony presents important contributions:

She [partner] was a bipolar person. I do not know if it was because of her previous relationship, in which her husband beat her constantly. She even had a restraining order. He nearly committed murder with her, it did not happen because someone showed up in the place. Then her brothers took action, and she separated from him.

Carlos's testimony demonstrates a repetition pattern of the marital choices made by his former partner. She had already been through a situation of extreme violence that could have culminated in her death, managing to survive, and unbound herself from her abuser. However, the risk remained present in her life, culminating effectively in her death, due to the expression of aggression of an intimate partner. A study carried out with women victim of domestic violence in which their life stories were also marked by violence and helplessness (repeated abandonment, violence between parents, sexual abuse, etc.) has shown that the marital choices made by these women are characterized as a desire to assign to others the function of freeing them from the traumatic experiences of the past and taking care of them, as an expression of passivity in face of the pain experienced in their life stories (Lima \& Werlang, 2011). The union between aggressor and victim cannot be considered a work of fate, but the expression of intense mental frailties. Therefore, it becomes imperative that men and women in the context of marital violence are focus of interest for scholars, so that health interventions are effective, as well as preventive measures. In this sense, we reinforce the importance of the creation of Law Maria da Penha and shall begin discussing the third and last part of this study.

\section{Third assertion: Law Maria da Penha and the reproduction of the sense of abandonment}

So that is what got me riled up, justice never supported me in any way. Whenever I sought justice, I never got it. They do whatever they want, say whatever they want, and the man has to lower his head (Vicente). 
Vicente's testimony demonstrates he relived of his feeling of abandonment given the consequences he suffered due to the aggression committed and the mechanisms that Law Maria da Penha created. Vicente had already been notified that his former partner had a restraining order against him due to the first physical abuse suffered. Then, Vicente became aggressive again, even more intensely, culminating with his arrest. However, Vicente acknowledges that he needed psychological and/or psychiatric aid, seeking help in an outpatient service, but finding no available appointments in his moments of greatest despair. The participant started receiving psychological, social, and mental care after being arrested. He believes that he went through several depressive episodes and that the Law should work differently:

Some days were horrible, so I sought out SUS. If we had a place that we sought out and were cared for I would not have come so far, in such an extreme, because the disease impacted me. I went to take this appointment. If the person is meant to do, he will do it [acted violently again, killing]. You are so humiliated, mistreated, that you leave here wanting revenge.

From Vicente's words, it seems relevant to discuss the concepts of projection and identification to the psychoanalytic theory, as these concepts are present not only in the dynamics of romantic relationships the participants established, but also in how they perceive their experiences in prison. The concept of projection deals with what the individual expels from within himself and gives to the other, such as feelings, desires, or "qualities" he refuses or is unaware of. The process of identification, on the other hand, can be understood as the mode by which the individual "assimilates an aspect, a property, an attribute of the other and transforms himself, totally or partially, according to this other's model" (Laplanche \& Pontalis, 2001, p. 226). Freud (1921/1996), in his text Group psychology and the analysis of the ego, claims that identification is the most remote manifestation of an emotional bond with another person. Thus, Laplanche and Pontalis (2001) point out that identification could work at the service of enriching the personality or the opposite, a situation "in which the object is put in the place of an instance" (p. 229). We can notice, from the life story of the men who participated in this research, that the remote emotional ties they established are characterized by helplessness and violence. Therefore, these men have incorporated a model of being and relating that they are unable to bear, requiring the projection mechanism to expel from within themselves their unwanted qualities. The projection seems to be present in the justifications used concerning the violence committed and, consequently, the fact of being under arrest. According to Vicente:

I am on medication. Who knows, if the guy took it before getting a restraining order. You give the guy a restraining order, but having already putting him on meds, making him find psychological assistance so that he will not reach his limits and hit again and be arrested. Do not let the guy lose himself. If you are going to a hearing and already have a restraining order is because the thing is already starting to boil. So before you let this boiled water spill, there could be treatment, a follow-up.

Carlos also shows the feeling of abandonment from the Law and from the current situation of detention, even thinking of suicide. In this sense, suicidal ideation, even not resulting in the consummated suicide, seems to represent a possibility of acting concerning that which cannot be metabolized psychically.

The law only judges you by the moment and does not look into your past. What matter is what the chief of police puts on the paper, you are judged for that. In the first five days I had, I had a thing, to find something to kill myself (Carlos).

Similarly to Carlos, João shows to be fully helpless in his condition of inmate and in extreme vulnerability: "What do you expect from the future? Nothing (he cries a lot, gets up from the chair, sighs, talks amid the tears that killing himself will not solve the problem)" (João).

It is believed that the marital aggressors need to have the condition to take the "reins" of their lives so they can take responsibility for the relations they establish and for the fate of the aggressiveness that belong to them. In this sense, there is a very important work space to be occupied by professionals in the field of health, particularly mental health. These men need to experience a relationship model that enables them to express their pain and the development of the past of suffering. It seems crucial that reflections are made in an interdisciplinary way from several spheres, such as social and legal, for example. Because, if these men do not feel in power of their life stories, the laws shall always meet a psyche that is unable to contain the expression in an act of the death drive.

The meeting between patient and analyst is characterized as a situation of communication between a person who arrives with words and crave an understanding that may nurse the pain, and another who listens to these words looking for the stranger that dwells in every individual (Dallazen, Giacobone, Macedo, \& Kupermann, 2012; Silva, 2013; Souza \& Coelho, 2012). It is important to highlight that during the data collection for this study, important meetings also occurred based on communication and on psychoanalytic ethics. From the availability to listen beyond words, we sought to understand the pain and suffering arising from a past of excesses and a present of extreme vulnerability. We aimed to open paths so that each participant would rethink their own story. From the moment we understand that healing comes through words, the ones who were patients become responsible for their attitudes, choices, and life itself. This understanding seems to contribute relevantly to the theme explored. We understand that this study may serve as a starting point so that research aiming to offer psychological interventions to marital aggressors may be developed with a larger number of participants. 


\section{References}

Amorim, P. (2000). Mini International Neuropsychiatric Interview (MINI): Validação de entrevista breve para diagnóstico de transtornos mentais [Mini International Neuropsychiatric Interview (MINI): Validation of a short structured diagnostic psychiatric interview]. Revista Brasileira de Psiquiatria, 22(3), 106-115. doi:10.1590/S1516-44462000000300003

Asnis, N. (2013). Homem-bomba: O sacrifício das pulsões [Man-bomb: The sacrifice of the drives]. Porto Alegre, RS: Buqui.

Asnis, N., Werlang, B. S. G., Macedo, M. M. K., \& Dockhorn, C. N. B. F. (2012). A pulsão de morte: Desde Freud, a dualidade do humano [The death drive: Since Freud, the duality of the human]. In M. M. K. Macedo, \& B. S. G. Werlang (Orgs.), Psicanálise e universidade: Potencialidades teóricas no cenário da pesquisa [Psychoanalysis and the university: Theoretical potentialities in the research scenario] (pp. 14-33). Porto Alegre, RS: EdiPUCRS.

Canavêz, F. (2013). Na outra cena da representação: Considerações ferenczianas sobre o trauma [In another scene of representation: Ferenczi's considerations about trauma]. Psicologia USP, 24(1), 165-182. doi:10.1590/ S0103-65642013000100009

Dallazen, L., Giacobone, R. V., Macedo, M. M. K., \& Kupermann, D. (2012). Sobre a ética em pesquisa na psicanálise [Considerations on ethics in research in psychoanalysis]. Psico, 43(1), 47-54. Retrieved from https://dialnet.unirioja.es/servlet/ articulo? codigo $=5163207$

Erickson, F. (1997). Métodos cualitativos de investigación sobre la enseñanza [Qualitative research methods on teaching]. In M. C. Wittrock (Comp.), La investigación de la enseñanza [Research on teaching] (pp. 195-301). Barcelona, España: Paidós.

Exner, J. E. (1999). Manual de classificação do Rorschach: Para o sistema compreensivo [Rorschach classification manual: For the comprehensive system]. São Paulo, SP: Casa do Psicólogo.

Exner, J. E., \& Sendín, C. (1999). Manual de interpretação do Rorschach: Para o sistema compreensivo [Rorschach interpretation manual: For the comprehensive system]. São Paulo, SP: Casa do Psicólogo.

Freud, S. (1996). Psicologia de grupo e análise do ego [Group psychology and ego analysis]. In J. Strachey (Ed.), Edição standard brasileira das obras psicológicas completas de Sigmund Freud [Standard edition of Sigmund Freud's complete psychological works] (J. Salomão, Trad., Vol. 18, pp. 87-179). Rio de Janeiro, RJ: Imago. (Trabalho original publicado em 1921).
Freud, S. (1996). On narcissism: Uma introdução [About narcissism: An introduction]. In J. Strachey (Ed.), Edição standard brasileira das obras psicológicas completas de Sigmund Freud [Standard edition of Sigmund Freud's complete psychological works] (J. Salomão, Trad., Vol. 14, pp. 77-81). Rio de Janeiro, RJ: Imago. (Trabalho original publicado em 1914).

Freud, S. (1996). Além do princípio de prazer [Beyond the principle of pleasure]. In J. Strachey (Ed.), Edição standard brasileira das obras psicológicas completas de Sigmund Freud [Standard edition of Sigmund Freud's complete psychological works] (J. Salomão, Trad., Vol. 18, pp. 11-72). Rio de Janeiro, RJ: Imago. (Trabalho original publicado em 1920).

Fulu, E., Jewkes, R., Roselli, T., \& Garcia-Moreno, C. (2013). Prevalence of and factors associated with male perpetration of intimate partner violence: Findings from the UN Multicountry Cross-sectional Study on Men and Violence in Asia and the Pacific. The Lancet Global Health, 1(4), e187-e207. doi:10.1016/S2214-109X(13)70074-3

Hirigoyen, M.-F. (2006). The violence in the couple: Da coação psicológica à agressão física [Violence in the couple: From psychological coercion to physical aggression]. Rio de Janeiro, RJ: Bertrand Brasil.

Laplanche, J., \& Pontalis, J.-B. L. (2001). Vocabulário da psicanálise [Vocabulary of psychoanalysis]. São Paulo, SP: Martins Fontes.

Lei No. 11.340, de 7 de agosto de 2006 (2006, 8 de agosto). Cria mecanismos para coibir a violência doméstica e familiar contra a mulher, nos termos do $\S 8^{\circ}$ do art. 226 da Constituição Federal, da Convenção sobre a Eliminação de Todas as Formas de Discriminação contra as Mulheres e da Convenção Interamericana para Prevenir, Punir e Erradicar a Violência contra a Mulher; dispõe sobre a criação dos Juizados de Violência Doméstica e Familiar contra a Mulher; altera o Código de Processo Penal, o Código Penal e a Lei de Execução Penal; e dá outras providências [Creates mechanisms to curb domestic and family violence against women, pursuant to $\S 8$ of art. 226 of the Federal Constitution, the Convention on the Elimination of All Forms of Discrimination against Women and the Inter-American Convention on the Prevention, Punishment, and Eradication of Violence against Women; provides for the creation of the Courts of Domestic and Family Violence against Women; amends the Criminal Procedure Code, the Criminal Code, and the Criminal Enforcement Law; among other measures]. Diário Oficial da União, seção 1.

Lima, G. Q., \& Werlang, B. S. G. (2011). Mulheres que sofrem violência doméstica: Contribuições da psicanálise [Women who suffer domestic violence: Contributions of psychoanalysis]. Psicologia em Estudo, 16(4), 511-520. doi:10.1590/S1413-73722011000400002 
Lima, G. Q, Werlang, B. S. G., \& Potrich, L. T. (2012). O efeito da repetição na escolha conjugal: Contribuições da psicanálise [The effect of repetition on conjugal choice: Contributions of psychoanalysis]. In M. M. K. Macedo, \& B. S. G. Werlang (Orgs.), Psicanálise e universidade: Potencialidades teóricas no cenário da pesquisa [Psychoanalysis and the University: Theoretical potentialities in the research scenario] (pp. 284-303). Porto Alegre, RS: EdiPUCRS.

Nardi, S. C. S., \& Benetti, S. P. C. (2012). Violência conjugal: Estudo das características das relações objetais em homens agressores [Marital violence: A study of characteristics of objectal relations in male offenders]. Boletim de Psicologia, 62(136), 53-66. Retrieved from http://pepsic.bvsalud. org/scielo.php?script $=$ sci_arttext\&pid $=$ S000659432012000100006\&lng=pt\&tlng=pt

Nascimento, R. S. G. F. (2010). Sistema compreensivo do Rorschach: Teoria, pesquisa e normas para a população brasileira [Rorschach's comprehensive system: Theory, research, and standards for the Brazilian people]. São Paulo, SP: Casa do Psicólogo.

Razera, J., \& Falcke, D. (2014). Relacionamento conjugal e violência: Sair é mais difícil que ficar? [Marital relation and violence: Is leaving harder than staying?]. Aletheia, (45), 156-167. Retrieved from http://pepsic.bvsalud.org/scielo.php? script $=$ sci $_{-}$ arttext\&pid=S1413-03942014000200012

Silva, D. Q. (2013). A pesquisa em psicanálise: O método de construção do caso psicanalítico [Research in psychoanalysis: Method of construction of the psychoanalytic case]. Estudos de Psicanálise, (39), 37-45. Retrieved from http://pepsic.bvsalud. org/scielo.php?script=sci_arttext\&pid=S010034372013000100004\&lng=pt\&tlng=pt

Souza, C. R. A., \& Coelho, D. M. (2012). O neutro em psicanálise: Da técnica à ética [The neuter in psychoanalysis: From technique to ethics]. Fractal: Revista de Psicologia, 24(1), 95-110. doi:10.1590/ S1984-02922012000100007

Stenzel, G. Q. L., \& Lisboa, C. S. M. (2017). Aprisionamento psíquico sob uma perspectiva psicanalítica: Estudo de caso de um agressor conjugal [Psychic imprisonment through a psychoanalytic view: A married aggressor case study]. Ágora: Estudos em Teoria Psicanalítica, 20(3), 625-633. doi:10.1590/1809-44142017003003

Tondowski, C. S., Feijó, M. R., Silva, E. A., Gebara, C. F. P., Sanchez, Z. M., \& Noto, A. R. (2014). Intergenerational patterns of family violence related to alcohol abuse: A genogram-based study. Psicologia: Reflexão e Crítica, 27(4), 806-814. doi:10.1590/16787153.201427421
Varón, G. C., \& Otero, J. L. P. (2014). Ciclo intergeneracional de la violencia doméstica contra la mujer: Análisis para las regiones de Colombia [Intergenerational cycle of domestic violence against women: Analysis for the regions of Colombia]. Revista de Economía del Caribe, (14). Retrieved from http://rcientificas.uninorte.edu.co/ index.php/economia/article/view/7062/6565

Gabriela Quadros de Lima Stenzel is a Ph.D. in Clinical Psychology at Pontifícia Universidade Católica do Rio Grande do Sul, Porto Alegre-RS, Brazil.

Carolina Saraiva de Macedo Lisboa is a Professor of the Pontifícia Universidade Católica do Rio Grande do Sul, Porto Alegre-RS, Brazil.

\section{Authors' Contribution:}

All authors made substantial contributions to the conception and design of this study, to data analysis and interpretation, and to the manuscript revision and approval of the final version. All authors assume public responsibility for the content of the manuscript.

Received: Feb. 3, 2017

${ }^{\text {st }}$ Revision: Jul. 30, 2017

$2^{\text {nd }}$ Revision: Mar. 15, 2018

Approved: Apr. 16, 2018

How to cite this article:

Stenzel, G. Q. L., \& Lisboa, C. S. M. (2019). Life history and personality characteristics of marital aggressors: Psychoanalytic contributions. Paidéia (Ribeirão Preto), 29, e2918 doi:http://dx.doi.org/10.1590/1982-4327e2918 